\title{
Development of Varieties of Spray from Production Plants and Utilization Waste in the Agribusiness Cultivation Chrysanthemum Cut Flower
}

\author{
I Gusti Made Arjana ${ }^{1}$, I Nyoman Rudianta ${ }^{2}$ \\ \{igmarjana@gmail.com ${ }^{1}$,yomanrudianta@yahoo.go.id $\left.{ }^{2}\right\}$ \\ Faculty of Agriculture University of Warmadewa Denpasar ${ }^{12}$
}

\begin{abstract}
This study entitled development of production plants and spray varieties utilization of waste in agribusiness cultivation Chrysanthemum cut flower, aims to find out the influence of spray and pemanfatan varieties of waste as well as its interaction on cultivation Chrysanthemum cut flower. Research method using random design with factorial pattern group of two factors, namely; the first factor is the type of the second factor varieties and kinds of waste. The results showed that treatment of a type of spray varieties provide a real influence on the parameter of interest $(\mathrm{cm})$ diameter, weight fresh economic interest $(\mathrm{g})$ and very real effect on the parameters of maximum plant height $(\mathrm{cm})$ of the flower stalk, height $(\mathrm{cm})$ and the diameter of the trunk $(\mathrm{cm})$. Treatment of waste sorts real influence on parameters of maximum plant height $(\mathrm{cm})$ of the flower stalks, length $(\mathrm{cm})$, diameter $(\mathrm{cm})$, fresh weight $(\mathrm{g})$ economic interest and a very real effect on the parameters of interest $(\mathrm{cm})$ in diameter. The interaction between the types of varieties of spray and kinds of waste are not real influence over all the parameters were observed. The results of the average weight of fresh flower varieties are present in highest economical Reagent of $79.08 \mathrm{~g}$ and low refractory i.e. Stroika varieties of $73.59 \mathrm{~g}$ and an increase in yield of $6.94 \%$ if compared with the varieties Stroika. While on the treatment of waste sorts the results of an average weight of fresh flowers there are highest in economically pemanfatan Lake of sludge waste $80.43 \mathrm{~g}$ and the lowest in pemanfatan waste water weeds of $75.54 \mathrm{~g}$ occur an increase of $6.08 \%$ if compared with useable waste water weeds.
\end{abstract}

Keywords: Chrysanthemum Cut Flower, Spray Varieties, Waste.

\section{Introduction}

Chrysanthemum (Dendranthema grandiflora, Tzvelev) also known as chrysanthemum, is an important commodity in the world on the international trade in ornamental plants and have economic value that is high enough so that the potential for expanded commercial. The prospect of the cultivation of chrysanthemums as a cut flower very bright, because of the potential market that could be powerless absorbency, it is still very wide open is associated with a very wide market needs in addition to the local market also export market. Currently the most popular flowers include chrysanthemums in Indonesia as cut flowers, as have the advantage of rich colors, assorted varieties, shapes and durable [1]. Chrysanthemum flower has a fairly high economic value and potential developed as a basic component in agribusiness as good as cut flowers, ornamental plants in pots, as well as a medicinal plant [2]. The results 
of the projection of the demand for chrysanthemum 2014-2019 year, estimated demand for chrysanthemum will continue to increase until the year 2019 to reach 70,676 tons, with an average of considerable growth i.e. $12.40 \%$ per year [3].

The management of the plant in a modern and efficient the many benefit farmers employed in various areas. Not all potential areas have been planted with ornamental plants, due to various considerations such as its location far from the center of marketing, there is no adequate infrastructure, the limitations of the knowledge cultivation, harvesting and postharvest handling as well as agroklimat which is not in accordance with the cultivation of Chrysanthemum plants [4].

Chrysanthemum cultivation business has developed in various production centers in Indonesia as a source of profitable farmers' income. Along with the increasing market demand, chrysanthemum cultivation which was initially concentrated on the island of Java, has now spread to Bali. The increasingly rapid development of tourism also has an impact on the diversity of horticultural products needed to meet the demands of a quality market and guaranteed product continuity, as Bali is a tourist destination so the market potential of chrysanthemums is very good for individual consumers such as florists, wedding events and great days. As well as institutional consumers (hotels, banks and government and private sector offices). So that the development of ornamental plants is directed towards referring to market needs, as well as comparative and economic value benefits. In addition, the development is in accordance with the potential of resources, agro-climate conditions, agroecosystem of a region, supporting facilities and infrastructure and market prospects. According to statistical data on ornamental plants, the Office of Agriculture of the Food Crops Province of Bali from 2005-2007 continued to increase ( $2005=14,909$ stalks, $2006=49,783$ stalks and $2007=59,587$ stalks).

The problem faced by farmers outside Java, especially Bali is the limited supply of quality chrysanthemum seeds originating from parent plants, which causes limited production capabilities and market continuity to consumers. Besides that, especially for chrysanthemum farmers outside Java, the biggest costs will come from the supply of cuttings from the parent plant, while the development of cuttings from parent plants for farmers requires substantial costs. And the determination of the type of soil enrichment material that is not in accordance with the conditions of cultivation, is the cause of the low production and quality of chrysanthemum flowers that affect the price of selling chrysanthemum as cut flowers. The high activity of human activities has many types of waste material produced which can be used as materials to enrich agricultural land that will be used for cultivation. Agricultural activities produce a variety of remaining crops that transport nutrients in the soil. Livestock activities produce livestock manure as a source of land enrichment. Water sources overgrown with weeds can be used as material to fertilize agricultural land such as sedimentation. Many abundant land enrichment materials around us that can be used as organic fertilizer in the cultivation of chrysanthemum plants, the type of waste will increase if it is not handled properly it will even be a source of environmental pollutants.

Based on the foregoing, it is necessary to do research on the development of plant spray varieties and the use of waste types in chrysanthemum cut flower agribusiness, the application of cultivation technology findings is expected to have a real impact on increasing income or welfare of local farmers, so farmers will be interested in adopting technology and develop it into the production system on the farm. 


\section{Methodology}

The research is located in Pancasari Village, Sukasada Subdistrict, Buleleng Regency, which is carried out in the field in a green house with a height of 1,247 meters above sea level and an average temperature of $17^{\circ} \mathrm{C}$ to $20^{\circ} \mathrm{C}$. The research method used factorial Randomized Completely Block Design using two factors, namely the first factor was the type of spray variety of production plants and the second factor was the type of waste, each of which consisted of: the first factor consisted of 3 levels, namely: Giant white ( $\mathrm{Vg}$ ); Reagent (Vr) and Stroika (Vs). While the second factor consists of 3 levels, namely: water weeds (Lg); lake mud $(\mathrm{Ll})$ and livestock waste $(\mathrm{Lt})$. The combined treatment of 9 was repeated 3 times, so 27 trial plots were needed. With a plot size of $2 \times 2 \mathrm{~m}$, the distance between plots is $30 \mathrm{~cm}$ and the distance between replications is $50 \mathrm{~cm}$.

The implementation of the experiment included land preparation as a growing medium, selection of varieties, preparation of waste, fertilization, planting, treatment, maintenance of plants (watering, replanting, weeding, pest and disease control), observation of plant growth and development. Parameters observed include; maximum plant height $(\mathrm{cm})$, flower stem length $(\mathrm{cm})$, stem diameter $(\mathrm{cm})$, flower diameter $(\mathrm{cm})$ and economical fresh weight $(\mathrm{g})$. Observation data were analyzed using an analysis of variance if a single treatment had a significant or very real effect followed by the smallest real difference test at the level of 5\%, and if there was a real or very real effect on the interaction followed by Duncan's multiple test $5 \%[5]$.

\section{Results and Discussion}

The significance of the effect of the treatment of varieties and types of waste and their interactions on all parameters observed in chrysanthemum plants is presented in Table 1. The results of the average influence between varieties and wastes on maximum plant height $(\mathrm{cm})$, flower stem length $(\mathrm{cm})$, stem diameter $(\mathrm{cm})$, flower diameter $(\mathrm{cm})$ and economical fresh weight $(\mathrm{g})$ are presented in Table 2.

Table 1. Significance of the results of analysis of the variance of the effect of treatment of varieties and types of waste and their interactions on all parameters observed in chrysanthemum plants

\begin{tabular}{lllcc}
\hline & & \multicolumn{2}{c}{ Treatment } \\
\cline { 3 - 5 } No & & Parameters & $\begin{array}{c}\text { Types of } \\
\text { varieties }\end{array}$ & $\begin{array}{c}\text { Types of } \\
\text { varieties x Types } \\
\text { of waste }\end{array}$ \\
\hline 1 & Maximum plant height $(\mathrm{cm})$ & $* *$ & $*$ & $\mathrm{~ns}$ \\
2 & Flower length $(\mathrm{cm})$ & $* *$ & $*$ & $\mathrm{~ns}$ \\
3 & Stem diameter $(\mathrm{cm})$ & $* *$ & $*$ & $\mathrm{~ns}$ \\
4 & Flower diameter $(\mathrm{cm})$ & $*$ & $* *$ & $\mathrm{~ns}$ \\
5 & Economical fresh weight $(\mathrm{g})$ & $*$ & $*$ & $\mathrm{~ns}$ \\
\hline
\end{tabular}

Description: $*=$ significant,$* *=$ highly significant, $\mathrm{ns}=$ non significant

The results of the analysis of variance showed that the treatment of varieties in various types had a significant effect on the parameters of flower diameter and fresh weight of economical flowers while significantly influencing the parameters of maximum plant height, 
flower stalk length and stem diameter. This shows that each type of variety that is tried gives a different response to vegetative and generative growth parameters. While the type of waste treatment appears to have a significant effect on the maximum plant height, stem length, stem diameter and fresh weight of economical flowers, and have a very significant effect on the diameter of the flower. The use of different wastes also causes differences in the development of chrysanthemum growth in Table 2 .

Whereas the interaction between varieties and types of waste treatment does not have a significant effect on all parameters observed in the growth and development of chrysanthemum plants, this is due to the variety in each species and the waste in each type has the same effect.

Table 2. The average effect of varieties and types of waste treatment on all observed parameters

\begin{tabular}{lccccc}
\hline Treatment & $\begin{array}{c}\text { Maximum plant } \\
\text { height }(\mathrm{cm})\end{array}$ & $\begin{array}{c}\text { flower stalk } \\
\text { length }(\mathrm{cm} \\
(\mathrm{cm})\end{array}$ & $\begin{array}{c}\text { Stem } \\
\text { diameter } \\
(\mathrm{cm})\end{array}$ & $\begin{array}{c}\text { Flower } \\
\text { diameter } \\
(\mathrm{cm})\end{array}$ & $\begin{array}{c}\text { Economical } \\
\text { weight of } \\
\text { fresh flowers } \\
(\mathrm{g})\end{array}$ \\
\hline $\begin{array}{l}\text { Type of variety } \\
\text { Giant White }\end{array}$ & $104.34 \mathrm{~b}$ & $124.85 \mathrm{~b}$ & $3.68 \mathrm{a}$ & $6.00 \mathrm{~b}$ & $78.98 \mathrm{a}$ \\
$\quad$ Reagent & $113.71 \mathrm{a}$ & $136.79 \mathrm{a}$ & $3.42 \mathrm{a}$ & $6.53 \mathrm{a}$ & $79.08 \mathrm{a}$ \\
Stroika & $102.23 \mathrm{~b}$ & $127.22 \mathrm{~b}$ & $3.14 \mathrm{~b}$ & $5.98 \mathrm{~b}$ & $73.59 \mathrm{~b}$ \\
\hline LSD5\% & 6.64 & 5.77 & 0.42 & 0.42 & 4.40 \\
\hline 2. Kinds of waste & & & & & \\
$\quad$ Water weeds & $107.11 \mathrm{ab}$ & $125.32 \mathrm{~b}$ & $3.11 \mathrm{~b}$ & $5.52 \mathrm{c}$ & $75.54 \mathrm{~b}$ \\
$\quad$ Lake mud & $111.06 \mathrm{a}$ & $133.45 \mathrm{a}$ & $3.74 \mathrm{a}$ & $6.87 \mathrm{a}$ & $80.43 \mathrm{a}$ \\
$\quad$ Livestock waste & $102.11 \mathrm{~b}$ & $130.09 \mathrm{ab}$ & $3.39 \mathrm{a} \mathrm{b}$ & $6.12 \mathrm{~b}$ & $75.68 \mathrm{~b}$ \\
\hline LSD 5\% & 6.64 & 5.77 & 0.42 & 0.42 & 4.40 \\
\hline D & & &
\end{tabular}

Description: The average value followed by the same letter on the same factor and column shows an insignificant effect on the 5\% LSD.

The treatment of Reagent varieties gave the development of maximum plant height, flower stalk length, stem diameter, flower diameter, and the highest fresh weight of economical flowers, followed by Giant white and stroika varieties. While the highest average weight of economical interest of $79.08 \mathrm{~g}$ was produced by Reagent varieties, followed by Giant white $79.89 \mathrm{~g}$ and Stroika varieties $73.59 \mathrm{~g}$. Reagent varieties do not appear to have a significant effect on Giant white varieties on the fresh weight of economical flowers. The highest yield of fresh weight of economical flowers was found in Reagent variety of $79.08 \mathrm{~g}$ and the lowest was in stroika varieties which was equal to $73.59 \mathrm{~g}$ and an increase in yield of $6.94 \%$ compared to Stroika variety.

Reagent and Giant white varieties, which are developed from cuttings of production plants, are still able to provide plant growth and development when compared to Stroika varieties, this shows that the production of plants cuttings still have the same ability as the parent plant as a source of cuttings for cultivation purposes . Vegetative breeding using genetically cuttings has uniformity from one individual that is bred, uniformity can occur because cell division in the vegetative parts occurs somatically, the parent chromosome replication becomes the same two, which also means the DNA replication possessed (Mangoendidjojo, 2003 in Intianingrum, et al., 2013).

In the use of waste types it can be seen that lake sludge wastes produce the highest average parameters at maximum plant height, flower stalk length, stem diameter, flower diameter, and 
the highest fresh weight of economic interest respectively: $111.6 \mathrm{~cm}, 133.45 \mathrm{~cm}, 3.74 \mathrm{~cm}$, $6.87 \mathrm{~cm}$ and $80.43 \mathrm{~g}$, followed by the use of livestock waste and water weeds. Lake mud does not appear to be significantly affected by water weeds on the development of maximum plant height. While the effect of lake mud sludge also does not appear with livestock waste in the parameters of flower stalk length, stem diameter and fresh weight of economical flowers.

The development of plants due to the provision of lake sludge is able to respond to chrysanthemum plants due to the inclusion of total $\mathrm{N}$ and total $\mathrm{P}$ from agricultural land of 22.46 tons / year and 2.44 tons / year to lakes, and community activities based on land use that provide the impact on water quality for the $\mathrm{N}$ and $\mathrm{P}$ parameters, respectively, is agriculture $(62.15 \%$ and $78.56 \%)$. The impact of community activities on total $\mathrm{N}$ intake and total $\mathrm{P}$ from the catchment area causes high levels of $\mathrm{N}$ and $\mathrm{P}$ in lake water. The agricultural zone shows total $\mathrm{N}(0.41 \mathrm{mg} / 1)$ and total $\mathrm{P}(0.90 \mathrm{mg} / 1)$ [6]. This situation also has an impact on the quality of lake mud containing elements needed for plant growth and development. Aquatic sediments are indicated to contain various organic and inorganic chemical elements because they are accumulated or accumulated from various chemical processes that occur in the waters. The results of the analysis also showed the presence of calcium and potassium in sediments, which are the elements needed in large quantities (macro nutrients) in fertilizers commonly used in agriculture and fisheries, where the concentration of these two elements in each fertilizer is different . Posphat found in waters will bind to other elements to form complex compounds and will dissolve or settle in sediments [7].

\section{Conclusion}

a. The interaction between the treatment of spray varieties and the types of waste does not appear to have significant effect on all parameters observed in the growth and development of chrysanthemum plants.

b. The treatment of varieties in various types has a significant effect on the parameters of flower diameter and fresh weight of economical flowers, while it has a very significant effect on the parameters of maximum plant height, flower stalk length and stem diameter.

c. The treatment of waste in various types of waste appears to have a significant effect on the maximum plant height, stem length and stem diameter and the fresh weight of economical flowers, and has a very significant effect on the diameter of the flower.

d. The highest yield of fresh economical weight is found in Reagent variety of $79.08 \mathrm{~g}$ and the lowest is in stroika variety which is equal to $73.59 \mathrm{~g}$ and an increase in yield of $6.94 \%$ compared to Stroika variety.

e. The highest average yield of fresh weight of economic interest is in utilization of lake mud waste of $80.43 \mathrm{~g}$ and the lowest utilization of water weed waste is $75.54 \mathrm{~g}$, an increase of $6.08 \%$ compared to utilization of water weed waste.

\section{Acknowledgment}

Many thanks to the Warmadewa University Research Institute for funding applied product research in 2018. As well as friends and students who have helped carry out this research.

\section{References}

[1] Sartika, D.: Kebun Bunga Potong Ciputri. Trubus, Jakarta (1998)

[2] Rukmana, H.: Krisan. Penerbit Kanisius, Yogyakarta (1997)

[3] Pusat Data dan Sistem Informasi Pertanian.: Out look Komoditi Krisan. Sekretariat Jendral, 
Kementerian Pertanian (2014)

[4] Darti.: Tanaman dan Budidaya Tanaman Hias. PD. Mahkota, Jakarta (1992)

[5] Hanafiah, K.: Rancangan Percobaan, Teori \& Aplikasi. PT. Raja Grafindo, Yogyakarta (2001)

[6] Endarini, T.: Dampak Kegiatan Masyarakat pada Kualitas air Danau Buyan, Kabupaten Buleleng. Program Studi Ilmu Lingkungan, Pasca Sarjana, Universitas Indonesia, Jakarta (2004)

[7] Elfrida.: Analisis Kandungan Organik dan Anorganik Sedimen Limbah Karamba Jaring Apung (KJA) di Danau Maninjau Propinsi Sumatera Barat. Skripsi UBH, Padang (2011)

[8] Badan Litbang Pertanian.: Peluang Bisnis Inovasi Krisan Badan Litbang Pertanian. Agro Inovasi. Edisi 7-14 Maret 2012. No. 3447 Tahun XLII (2012)

[9] Balai Penelitian Tanaman Hias.: Teknologi Produksi Krisan. Pusat Penelitian dan Pengembangan Hortikultura Badan Penelitian dan Pengembangan Pertanian (2006)

[10] Direktorat Budidaya dan Pascapanen Florikultura.: Profil Krisan. Dirjen Hortikultura, Kementrian Pertanian (2013)

[11] Direktorat Budidaya dan Pascapanen Florikultura.: Profil Cluster Bali. Dirjen Holtikultura, Kementrian Pertanian (2011)

[12] Direktorat Budidaya dan Pascapanen Florikultura.: Profil Krisan. Dirjen Holtikultura, Kementrian Pertanian (2013)

[13] Moningka, I.V., Sinolungan, M.T.M., Kaunang, D., \& Kawulusan, R.: Sifat Fisik dan Kimia Sedimen pada Danau (2014)

[14] Magoensoeparjo., Soepadiyo., \& Toekidjan, S.: Ilmu Gulma dan Pengelolaanya pada Budidaya Perkebunan. Gadjah Mada University Press, Yogyakarta (2015)

[15] Marwanto, B., Suhardi, Y.Sulyo, K. Effendie, dan Y. Hilman.: Teknologi Produksi Krisan. Pengembangan Hortikultura Badan Penelitian dan Pengembangan Pertanian Pertanian. Persada, Jakarta (2006) 